\title{
An Empirical Analysis of Obesity Kuznets Curve Model for the Eurasian Economic Union
}

\author{
Ph.D. Candidate Ayşe Öcal (Doğuş University, Turkey)
}

\begin{abstract}
This paper aims to analyse the relationship between obesity and economic growth in the context of the Obesity Kuznets Curve model for the Eurasian Economic Union for the years between 2000-2016. The relationship between obesity rates and the real gross domestic product has been examined for the Eurasian Economic Union in the context of the Obesity Kuznets Curve model using the fixed-effects model. The results show that the Obesity Kuznets Curve Model is valid for the Eurasian Economic Union. Therefore, this paper points out that the relationship between obesity rates and economic growth within the Eurasian Economic Union is non-linear.
\end{abstract}

\section{Introduction}

Obesity is a health status that causes mortal and morbid risks for individuals with a body mass index of 30 and more. Body mass index is medically used to determine whether an individual is obese or not. A person's body mass index is calculated by dividing his weight in kilograms into the square of his height in meters (World Health Organization, 2021).

Obesity had been defined as a medical problem for years affecting individuals mentally and physically. Besides its medical results, obesity has been examined within the scope of health economics regarding its economic background and consequences. Economic growth, unemployment, household income, gender, age, marital status, etc., have been found in the health economics literature as a trigger of gaining weight. Numerous empirical analyses in the literature have stated that economic growth is one of the primary motivations behind the obesity problem for individuals.

Eating habits are generally considered an outcome of rational behaviours of individuals that can be affected by any changes in costs (McCarthy, 2004). Moreover, changes in income may also have significant impacts on eating habits and lifestyle by affecting individuals' decisions.

In 1955, Simon Kuznets analysed a model that examines the relationship between economic growth and income inequality and found a non-linear relationship between these two variables (Kuznets, 1955). After years, the model has renamed the Environmental Kuznets Curve, analysing the non-linear relationship between environment and economic growth (Grossman and Krueger, 1995).

Grecu and Rothoff first presented the Obesity Kuznets Curve Model in 2015 to describe the non-linear relationship between economic growth and obesity (Grecu and Rothoff, 2015). Their study pointed out that people become eligible to have more nutrition as income rises, ending with weight gain. However, considering health is a normal good, people pay more attention to their health as income continues to rise and they start to lose weight.

The Eurasian Economic Union officially established in 1994 consisting of Armenia, Belarus, Kazakhstan, Kyrgyzstan, and the Russian Federation as its member countries. The union had experienced rapid growth in their economies between 2000-2016, with a growing obesity rate for the given years as well. Figure 1 shows the trend of the economic growth and the obesity rates within the union between 2000 and 2016.

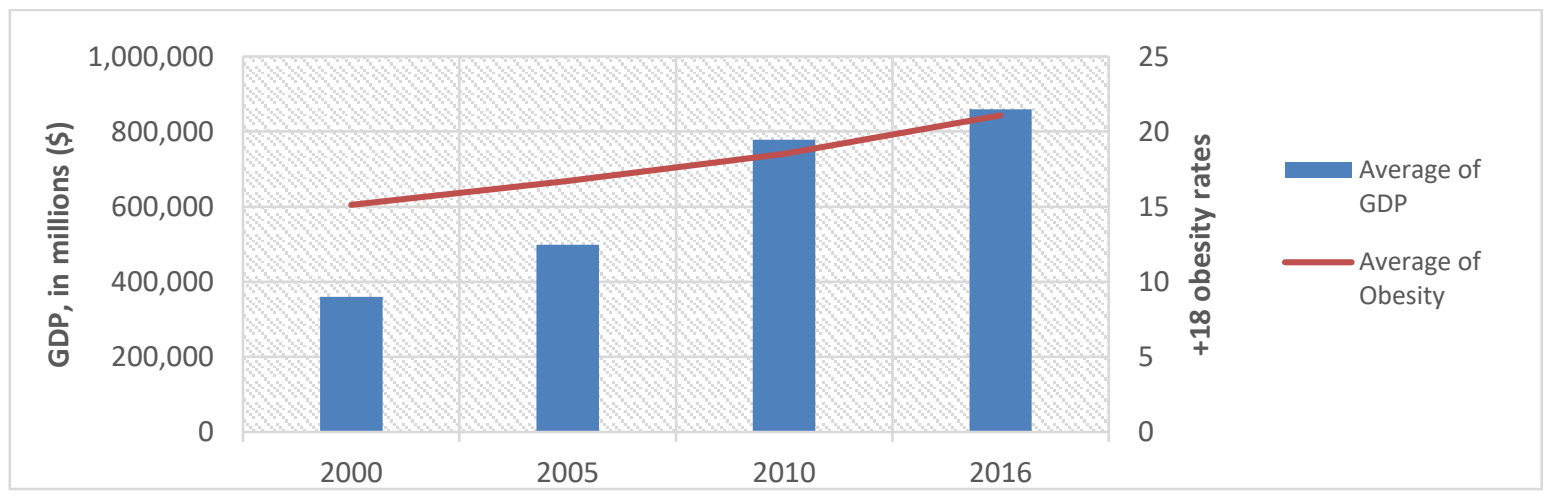

Figure 1. GDP and obesity rates (2000-2016) Source: Penn World Table and World Health Organization databank

In the Obesity Kuznets Curve Model framework, we analysed the relationship between obesity and economic growth for the Eurasian Economic Union between 2000-2016. According to the best knowledge of the author of this paper, this study contributes to the literature by using the expenditure-side real gross domestic product at 
current purchasing power parity in the Obesity Kuznets Curve Model testing this model to analyse the relationship between obesity rates and economic growth for the Eurasian Economic Union.

\section{Literature Review}

Literature does not have numerous studies about the relationship between obesity and economic growth. However, there are notable studies in the literature using different methods and data in order to analyse the relationship between economic growth and obesity.

\begin{tabular}{|c|c|c|c|c|}
\hline Author\&Year & Period & Sample & Methodology & Findings \\
\hline $\begin{array}{l}\text { Egger, Islam \& } \\
\text { Swinburn, } 2012\end{array}$ & 2007 & $\begin{array}{l}175 \\
\text { countries }\end{array}$ & $\begin{array}{l}\text { Spline } \\
\text { regression } \\
\text { analyses }\end{array}$ & $\begin{array}{l}\text { Positive relationship between GDP per capita } \\
\text { and BMI up to } \$ 3000 \text {. Above } \$ 3000 \text {, found no } \\
\text { significant relationship between two variables. }\end{array}$ \\
\hline $\begin{array}{l}\text { Goryakin \& } \\
\text { Suhrcke, } 2014\end{array}$ & 1991- 2009 & 56 countries & $\begin{array}{l}\text { OLS \& fixed } \\
\text { effects }\end{array}$ & $\begin{array}{l}\text { Prevalance of overweight is likely to increase in } \\
\text { low-income countries as GDP per capita } \\
\text { decreases } 1 \% \text { and more. }\end{array}$ \\
\hline \begin{tabular}{|l|} 
Gortmaker, \\
Kawachi, Neuman \& \\
Subramanian, 2014 \\
\end{tabular} & $1991-2010$ & 38 countries & $\begin{array}{l}\text { Ordered } \\
\text { multinomial } \\
\text { model }\end{array}$ & $\begin{array}{l}\text { Positive but insignificant relationship between } \\
\text { GDP per capita and BMI, particularly in rural } \\
\text { and poor regions. }\end{array}$ \\
\hline $\begin{array}{l}\text { Grecu \& Rotthoff, } \\
2015\end{array}$ & $1991-2010$ & USA & $\begin{array}{l}\text { Differences-in- } \\
\text { differences }\end{array}$ & $\begin{array}{l}\text { Non-linear relationship between obesity and } \\
\text { household income. }\end{array}$ \\
\hline $\begin{array}{l}\text { Murphy, Lawson \& } \\
\text { Williamson, } 2016\end{array}$ & $\begin{array}{l}1995 \text { and } \\
2000-2009\end{array}$ & $\begin{array}{l}135 \\
\text { countries }\end{array}$ & $\begin{array}{l}\text { Pooled OLS \& } \\
\text { fixed effects }\end{array}$ & $\begin{array}{l}\text { Positive relationship between BMI and income } \\
\text { among men, negative relationship among } \\
\text { women in developed countries. }\end{array}$ \\
\hline Pisa \& Pisa, 2016 & 1998- 2012 & South Africa & $\begin{array}{l}\text { Unadjusted time } \\
\text { trend plot }\end{array}$ & $\begin{array}{l}\text { Positive relationhsip between GDP per capita } \\
\text { and obesity. }\end{array}$ \\
\hline $\begin{array}{l}\text { Ameye \& Swinnen, } \\
2019\end{array}$ & 1976- 2016 & $\begin{array}{l}\text { Low, middle } \\
\text { and upper } \\
\text { income } \\
\text { countries }\end{array}$ & $\begin{array}{l}\text { Literature } \\
\text { review }\end{array}$ & $\begin{array}{l}\text { Obesity rises as income rises in low-income } \\
\text { countries; no relationship in middle-income } \\
\text { countries; falls as income rises in upper-income } \\
\text { countries. }\end{array}$ \\
\hline $\begin{array}{l}\text { Asal, Fox \& Wengel, } \\
2019\end{array}$ & $1980-2008$ & $\begin{array}{l}190 \\
\text { countries }\end{array}$ & $\begin{array}{l}\text { Two-way-fixed- } \\
\text { effects \& OLS }\end{array}$ & $\begin{array}{l}\text { Curvelinear relationship between obesity and } \\
\text { GDP per capita. Positive relationship between } \\
\text { economic growth and BMI in low-income } \\
\text { countries; negative relationship in upper-income } \\
\text { countries. }\end{array}$ \\
\hline Aydın, 2019 & $1991-2016$ & 20 countries & $\begin{array}{l}\text { Bounds test- } \\
\text { ARDL }\end{array}$ & $\begin{array}{l}\text { Non-linear relationship between economic } \\
\text { growth and obesity in the long-run. Obesity } \\
\text { increases as economy grows and falls as } \\
\text { economy contious to grow. }\end{array}$ \\
\hline \begin{tabular}{|l|} 
Bendavid, Dieleman, \\
Hashiguchi, Templin \\
\& Thomson, 2019 \\
\end{tabular} & $1995-2016$ & $\begin{array}{l}103 \\
\text { countries }\end{array}$ & $\begin{array}{l}\text { Logistics } \\
\text { regression \& } \\
\text { fixed-effects }\end{array}$ & $\begin{array}{l}\text { Obesity decreases with incerasing GDP per } \\
\text { capita in wealthy group but increases in less } \\
\text { wealthy group. }\end{array}$ \\
\hline $\begin{array}{l}\text { Hlaing, Kakinaka \& } \\
\text { Windarti, } 2019\end{array}$ & $1975-2010$ & $\begin{array}{l}130 \\
\text { countries }\end{array}$ & $\begin{array}{l}\text { OLS-Dynamic } \\
\text { panel regression } \\
\text { analysis } \\
\end{array}$ & $\begin{array}{l}\text { Obesity rises as income rises in low-income } \\
\text { countries; falls as income rises in upper-income } \\
\text { countries. }\end{array}$ \\
\hline $\begin{array}{l}\text { Talukdar, } \\
\text { Seenivasan, } \\
\text { Cameron and Sacks, } \\
2020\end{array}$ & $2019-2024$ & $\begin{array}{l}147 \\
\text { countries }\end{array}$ & $\begin{array}{l}\text { Bayesian } \\
\text { hierarchical } \\
\text { model }\end{array}$ & $\begin{array}{l}\text { Positive relationship between obesity prevalence } \\
\text { and national income but there is no evidence for } \\
\text { obesity kuznets curve. }\end{array}$ \\
\hline
\end{tabular}

Table 1. Literature review on the relationship between obesity and income

\section{Data, model, and methodology}

This paper covers the data for the years between 2000-2016 for the Eurasian Economic Union. The union consists of 5 countries: Armenia, Belarus, Kazakhstan, Kyrgyzstan, and Russian Federation.

This study obtained the obesity data $(O B)$ from the World Health Organization database, expenditure-side real gross domestic product at current purchasing power parity (in million 2017 US dollars) data (GDP) and the GDP square $\left(G D P^{2}\right)$ from the Penn World Table, version 10.0 database, for the years between 2000-2016. 
The relationship between obesity rates and the real gross domestic product is examined for the Eurasian Economic Union in the context of the Obesity Kuznets Curve Model. The function for the Obesity Kuznets Curve Model is defined as follows:

$$
O B=f\left(G D P, G D P^{2}\right)
$$

The model to be estimated for the function is as follows:

$$
O B_{t}=\beta_{0}+\beta_{1} G D P_{t}+\beta_{2} G D P_{t}^{2}+\varepsilon_{t}
$$

In equation (2) $\beta_{1}$ and $\beta_{2}$ stand for the coefficients of the real gross domestic product and the real gross domestic product square, respectively.

The Obesity Kuznets Curve model offers that people start to eat more than they need once the income level increases until they realize the importance of their health, and they change their eating habits into a healthy diet (Grecu and Rotthoff, 2015). We therefore hypothesise that the coefficient of GDP is expected to be positive, and the coefficient of $G D P^{2}$ is expected to be negative.

We used the cross-section dependence test to analyse the relationship between the cross-sections. First, the stationary levels of the variables were tested using two different unit root tests consisting Augmented Dickey Fuller (Dickey and Fuller, 1981) and Phillips Perron (Phillips and Perron, 1988). Later on, the fixed-effects model was used with estimating generalized least squares. We also investigated the co-integration between variables since they are stationary at first difference.

\section{Empirical Results}

First off, we tested the cross-section dependence between cross-sections in the data. This test hypothesises that there is no cross-section between the cross-sections. According to the results, the null hypothesis is rejected, meaning there is a cross-section dependence between the cross-sections in the study sample.

\begin{tabular}{|llll|}
\hline \multicolumn{1}{|c|}{ Test } & Statistic & d.f. & Prob. \\
\hline Breusch-Pagan LM & 78.73918 & 10 & 0.0000 \\
Pesaran scaled LM & 15.37055 & & 0.0000 \\
Bias-corrected scaled LM & 15.21430 & & 0.0000 \\
Pesaran CD & 6.839777 & & 0.0000 \\
\hline
\end{tabular}

Table 2. Cross section dependence test result

We applied unit root tests to determine the stationary levels of the variables. The results of the unit root tests show that obesity, the real gross domestic product, and the real gross domestic product square variables are stationary at first difference. Table 3 shows the results obtained from the unit root tests.

\begin{tabular}{|llll|}
\hline & OB & GDP & GDP sqauare \\
\hline ADF & $77.44(0.000)^{*}$ & $18.73(0.044)^{* *}$ & $21.58(0.017)^{* *}$ \\
\hline PP & $98.16(0.000)^{*}$ & $35.10(0.000)^{*}$ & $44.44(0.000)^{*}$ \\
\hline Probability values are in parentheses. ${ }^{*}$ stands for $1 \%$ significance level and ${ }^{* *}$ stands for 5\% significance level. \\
\hline
\end{tabular}

Table 3. Summary of unit root test results

Since the unit root test results show that all variables are stationary at the first difference, we used the Pedroni (Pedroni, 1999) co-integration test to detect the co-integration between the variables. According to the results, with the rejection of the null hypothesis, which offers no integration, there is a co-integration between obesity and explanatory variables.

\begin{tabular}{|l|l|l|c|c|}
\hline & Statistic & Prob. & Weighted Statistic & Prob. \\
\hline Panel v-Statistic & 253.4047 & 0.0000 & 237.2488 & 0.0000 \\
\hline Panel rho-Statistic & 0.025315 & 0.5101 & -0.018238 & 0.4927 \\
\hline Panel PP-Statistic & -3.030553 & 0.0012 & -3.025234 & 0.0012 \\
\hline Panel ADF-Statistic & -3.395552 & 0.0003 & -3.463470 & 0.0003 \\
\hline
\end{tabular}

Table 4. Pedroni residual co-integration test results

The Obesity Kuznets Curve Model to be estimated for the Eurasian Economic Union is as follows:

$$
O B_{t}=\beta_{0}+\beta_{1} G D P_{t}+\beta_{2} G D P_{t}^{2}+\varepsilon_{t} \text {. }
$$

The model hypothezises that the coefficients of the explanatory variables are expected to be $b_{1}>0$ and $b_{1}<0$. According to the fixed effects model results, the real GDP positively impacts obesity rates while the real GDP square negatively affects the obesity rates. These findings suggest that an increase in the real GDP within the union 
will raise the obesity rates but as long as the real GDP continues to rise, obesity rates will fall. Overall, the results show that the Eurasian Economic Union will experience the Obesity Kuznets Curve Model.

\begin{tabular}{|l|l|}
\hline Variable & Result \\
\hline GDP in millions (\$) & $15.2908 * * * \quad(1.5672)$ \\
\hline GDP in millions (\$) square & $-2.4880 * * \quad(0.2817)$ \\
\hline Constant term (c) & $12.3237 * * \quad(0.5237)$ \\
\hline Sample & 85 \\
\hline R square & 0.8507 \\
\hline Statistical significance $* * * \mathrm{p}$ value $<0.01$ & \\
\hline
\end{tabular}

Table 5. Fixed effects model test results

\section{Conclusion}

This study examined the relationship between obesity and economic growth in the context of the Obesity Kuznets Curve Model for the Eurasian Economic Union for the years between 2000-2016. We used a single model for the Obesity Kuznets Curve Model equation. Firstly, the stationary levels of variables have been examined. Later on, we estimated Pedroni (Pedroni, 1999) residual test to find if there is a co-integration between variables. Consequently, we obtained the results that the Eurasian Economic Union will experience the Obesity Kuznets Curve Model. This result, therefore, suggests that the obesity rates in the Eurasian Economic Union would increase as the economy grows but start decreasing with continuous growth in the economy.

The findings show that this study has notable outcomes in line with the literature stating that the obesity rates are likely to increase with economic growth and start to fall as the economy grows. Therefore, this result points out that the relationship between obesity and economic growth within the Eurasian Economic Union is non-linear. Nonetheless, the relationship between obesity and economic growth differs regarding the nature of the studies in the literature. There are various empirical studies in the literature suggesting different results. The relationship between obesity and economic growth has been found insignificant in rural and impoverished regions (Gortmaker, Kawachi, Neuman \& Subramanian, 2014). In contrast, there are mixed results according to the income level of the countries (Ameye \& Swinnen, 2019). Aydin (2019) found that the Obesity Kuznets Curve model is valid for Oman, Saudi Arabia, Turkey, and the United Arab Emirates between 1991 and 2016.

Although the Eurasian Economic Union would experience Obesity Kuznets Curve Model with a growing economy, other utmost economic determinants may lead the fluctuations in obesity rates into a different pattern. Therefore, further studies should analyse the other income-related motivations behind obesity, such as household income, disposable income, etc., to determine whether the relationship between obesity rates and other incomerelated variables is linear or non-linear.

\section{References}

- Ameye and Swinnen, 2019. "Obesity, income and gender: The changing global relationship", Global Food Security, 23, p. 267-281.

- Aydın, 2019. "The effect of economic growth on obesity for the most obese countries: new evidence from the obesity Kuznets curve", The European Journal of Health Economics, 20, p.1349-1358.

- Dickey and Fuller, 1981. "Likelihood ratio statistics for autoregressive time series with a unit root", Econometrica, 49, 4, p. 1057- 1072.

- Egger, Swinburn and Islam, 2012. "Economic growth and obesity: An interesting relationship with worldwide implications", Economics and Human Biology, 10, 2, p. 147- 153.

- Feenstra, Inklaar and Timmer, 2015. "The Next generation of the Penn World Table", American Economic Review, 105, 10, p. 3150-3182.

- Fox, Feng and Asal, 2019. "What is driving global obesity trends? Globalization or "modernization"?", Globalization and Health, 15:32, p. 1-16.

- Goryakin and Suchrke, 2014. "Economic development, urbanization, technological change and overweight: What do we learn from 244 Demographic and Health Surveys?”14, p. 109-127.

- Gortmaker, Kawachi, Neuman and Subramanian, 2014. "National economic development and disparities in body mass index: A cross-sectional study of data from 38 countries”, PLoS One, 9, 6, e99327

- Grecu and Rotthoff, 2015. "Economic growth and obesity: findings of an Obesity Kuznets curve", Applied Economics Letter, 22, 7, p. 539- 543. 
- Grossman and Krueger, 1995. "Economic growth and environment", The Quarterly Journal of Economics, 110,2 , p. $353-377$.

- Kuznets, 1955. "Economic growth and income inequality", American Economic Review, 45, 1, p. 1-28.

- Lawson, Murphy and Williamson, 2016. "The relationship between income, economic freedom, and BMI", Public Health, 134, p. 18-25.

- McCarthy, 2004. “The Economics of Obesity”, The Lancet World Report, 364, 9452, p. 2169-2170.

- Pedroni, 1999. "Critical values for cointegration tests in heterogenous panels with multiple regressors", Oxford Bulletin of Economics and Statistics, Special Issue, p. 653- 670.

- Phillips and Perron, 1988. "Testing for a unit root in time series regression”, Biometrika, 75, 2, p. 335 - 346.

- Pisa and Pisa, 2016. "Economic growth and obesity in South African adults: an ecological analysis between 1994 and 2014", The European Journal of Public Health, 27, 3, p. 404- 409.

- Talukdar, Seenivasan, Cameron and Sacks, 2020. "The association between national income and adult obesity prevalence: Empirical insights into temporal patterns and moderators of the association using 40 years of data across 147 countries, PLoS One, 15, 5, e0232236.

- Templin, Hashiguchi, Thomson, Dieleman and Bendavid, 2019. "The overweight and obesity transition from the wealthy to the poor in low-and middle-income countries: A survey of household data from 103 countries", PLoS Med, 16, 11, e1002968.

- The Eurasian Economic Union, 2021. Timeline, http://www.eaeunion.org/?lang=en\#about-history

- Windarti, Hlaing and Kakinaka, 2019. “Obesity Kuznets curve: international evidence”, Public Health, 169, p. 26-35.

- World Health Organization, 2021. Obesity, https://www.who.int/topics/obesity/en/

- World Health Organization, 2021. The Global Health Observatory, https://www.who.int/data/gho 